\title{
Commentary: Left ventricular free wall rupture: Patch and unload?
}

\author{
J. James Edelman, PhD, MBBS(Hons), Hiroto Kitahara, MD, and Vinod H. Thourani, MD
}

\footnotetext{
From the Department of Cardiac Surgery, MedStar Heart and Vascular Institute, Georgetown University School of Medicine, Washington, DC.

Disclosures: Authors have nothing to disclose with regard to commercial support.

Received for publication Feb 24, 2019; accepted for publication Feb 25, 2019; available ahead of print April 5, 2019.

Address for reprints: Vinod H. Thourani, MD, Department of Cardiac Surgery, MedStar Heart and Vascular Institute, Georgetown University School of Medicine, 110 Irving St, Ste 6D15G, Washington, DC 20010 (E-mail: vinod.h.thourani@medstar.net).

J Thorac Cardiovasc Surg 2019;158:778-9

$0022-5223 / \$ 36.00$

Copyright (c) 2019 by The American Association for Thoracic Surgery

https://doi.org/10.1016/j.jtcvs.2019.02.116
}

Left ventricular free wall rupture (LVFWR), is a rare event in the era of percutaneous coronary intervention and thrombolysis- $0.2 \%$ to $0.5 \%$ in modern series-because most full-thickness myocardial infarctions are prevented by timely presentation to hospital and revascularization ${ }^{1,2}$

William Harvey first described LVFWR at autopsy in the mid 17th century. ${ }^{3}$ Hatcher and colleagues ${ }^{4}$ described the first long-term outcomes of 3 patients who underwent surgery between 1968 and 1971 using horizontal mattress sutures through the surrounding myocardium with large polytetrafluoroethylene felt strips. Two of their 3 patients survived beyond 1 year. Núñez and colleagues ${ }^{5}$ described the use of a large polytetrafluoroethylene patch over the rupture secured by continuous 2-0 polypropylene suture in the surrounding normal myocardium on cardiopulmonary bypass (CPB) between 1980 and 1981. ${ }^{5}$ Padró and colleagues ${ }^{6}$ first described the use of a sutureless technique in 13 patients operated on between 1986 and 1991 without using CPB. They placed a large $5 \mathrm{~cm} \times 8 \mathrm{~cm}$ polytetrafluoroethylene patch over the defect and fixed it with topical tissue adhesive. They noted no mortality in their series.

Okamura and colleagues ${ }^{7}$ describe what must be among the largest surgical series of LVFWR to date. Between 2001 and 2016, the group applied a hemostatic collagen patch, often with fibrin glue, in 35 patients without CPB. Fifty-three percent of LVFWRs were in lateral or inferior wall territories; the authors used an off-pump coronary artery bypass stabilizer to optimize exposure without hemodynamic compromise. Rerupture occurred in 6 of 35 patients $(17 \%)$ and was an independent predictor of inhospital and midterm mortality. Rerupture occurred away from the original area of rupture. Three patients required subsequent mitral valve surgery and another developed a ventricular septal defect that was surgically repaired. Twenty-nine of 35 patients $(83 \%)$ survived to discharge. Of 6 patients who died, 3 had rerupture. Another 6 patients died during the first year of follow-up, highlighting the poor repair.

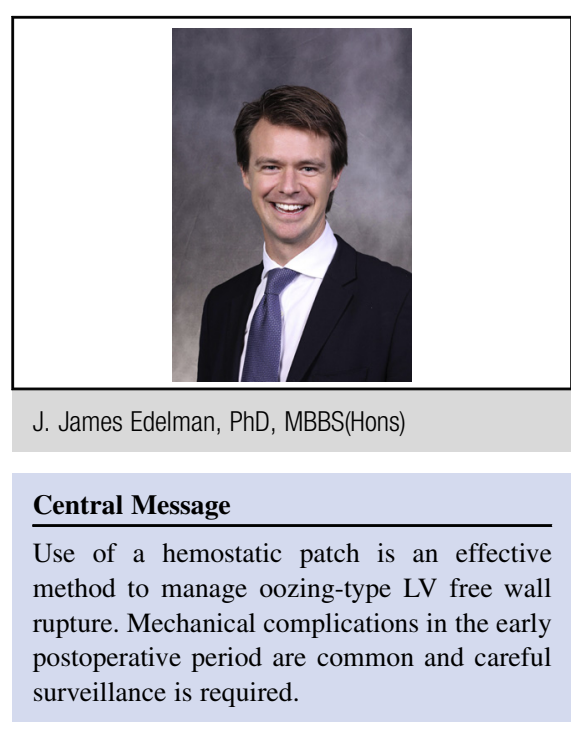

See Article page 771 .

prognosis of this condition even after successful surgical

Okamura and colleagues ${ }^{7}$ are to be congratulated on their results in this high-risk patient group that support the use of this technique in the oozing form of LVFWR. The technique is advantageous because it can be performed in all territories of the heart without the need for CPB and heparinization and is not particularly technically demanding. Meticulous monitoring of patients during the postoperative period is required for early detection of subsequent mechanical complications. Clearly, in those with more aggressive forms of LVFWR, a more traditional surgical intervention of resection and patch repair is required.

Further thought should be directed toward preventing the mechanical complications that occurred postoperatively in approximately $26 \%$ of patients-2 ruptured papillary muscles, 1 ventricular septal defect, and 6 reruptures. Unloading the ventricle postoperatively may benefit with intra-aortic balloon pump, the Impella device (Abiomed, Danvers, Mass), and/or left ventricular assist device. An Impella 5.0 may be preferable because it can be placed via an axillary artery to allow early mobilization and can completely unload the left ventricle. ${ }^{8-11}$ This may prevent complications during the vulnerable period of coagulative necrosis when the muscle is weakest, but has the downside of low-level heparinization. 
Although rare, continued improvement in techniques is required for the management of this lethal disease. We encourage longer-term follow-up of survivors of LVFWR to determine the durability of this novel technique.

\section{References}

1. French JK, Hellkamp AS, Armstrong PW, Cohen E, Kleiman NS, O'Connor CM, et al. Mechanical complications after percutaneous coronary intervention in STelevation myocardial infarction (from APEX-AMI). Am J Cardiol. 2010;105: 59-63.

2. Lopez-Sendon J, Gurfinkel EP, Lopez de Sa E, Agnelli G, Gore JM, Steg PG, et al. Factors related to heart rupture in acute coronary syndromes in the Global Registry of Acute Coronary Events. Eur Heart J. 2010;31:1449-56.

3. Kendall RW, DeWood MA. Postinfarction cardiac rupture: surgical success and review of the literature. Ann Thorac Surg. 1978;25:311-5.

4. Cobbs BW, Hatcher CR, Robinson PH. Cardiac rupture. Three operations with two long-term survivals. JAMA. 1973;223:532-5.
5. Núñez L, la Liana de R, Lopez-Sendon J, Coma I, Aguado MG, Larrea JL. Diagnosis and treatment of subacute free wall ventricular rupture after infarction. Ann Thorac Surg. 1983;35:525-9.

6. Padró J, Mesa J, Silvestre J, Larrea J, Caralps J, Cerrón F, et al. Subacute cardiac rupture: repair with a sutureless technique. Ann Thorac Surg. 1993;55:20-4.

7. Okamura H, Kimura N, Mieno M, Matsumoto H, Yuri K, Yamaguchi A. Sutureless repair for postinfarction left ventricular free wall rupture. J Thorac Cardiovasc Surg. 2019;158:771-7.

8. Bertoglio L, Katsarou M, Scandroglio M, Bertoldi L, Chiesa R, Pappalardo F. Surgical transaxillary placement of the Impella 5.0 ventricular assist device. $J$ Card Surg. 2019;34:92-8.

9. Dahlin L-G, Peterzén B. Impella used for hemostasis by left ventricular unloading, in a case with left ventricular posterior wall rupture. Ann Thorac Surg. 2008 85:1445-7.

10. Westaby S, Mehta V, Flynn F, Wilson N. Mechanical left ventricular unloading to prevent recurrent myocardial rupture. J Thorac Cardiovasc Surg. 2010;140:e16-7.

11. Zhang Z-P, Su X, Liu C-W, Song D, Peng J, Wu M-X, et al. Use of intra-aortic balloon pump support for oozing-type cardiac rupture after acute myocardial infarction. Am J Emerg Med. 2016;34:120.e1-3. 